\title{
Engineering Properties of Some Basement Rocks of Nigeria as Aggregate in Civil Engineering Pavement Construction
}

\author{
Falowo Olumuyiwa Olusola
}

Department of Geology, University of Benin, Benin City, Edo State, Nigeria. Email:solageo@yahoo.co.uk Tel: +2348025965896

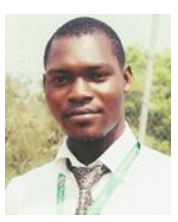

\begin{abstract}
The engineering performance of construction materials is strongly related to their physical properties. Therefore in order to determine the suitability of the rock units in northern parts of Ondo State, Nigeria as aggregates for pavement construction, eight rock samples comprising porphyritic granite, granite, migmatite, granite gneiss, quartz schist, granodiorite, charnockite, and quartzite, were subjected to physical tests which include moisture content, dry density, porosity, specific gravity, aggregate impact value, aggregate crushing value, point load strength index, unconfined compressive strength, and shear strength. The tests were conducted in accordance to ASTM D22 16 and ISRM-2386 standard test methods. The aggregate impact value of the samples ranges from 11.2 (Quartzite/granite gneiss) to 17.3 (Charnockite), while aggregate crushing value varies from 18.4 (Quartzite) to 25.2 (Charnockite). The water absorption of the rock units ranges between 0.27 and $0.82 \%$, and porosity recorded $0.18-0.46 \%$. Point load strength index, shear strength, and unconfined compressive strength of the samples ranges from $7.40-9.87,60.5-92.6 \mathrm{MPa}$, and 121.1 - 185.3 respectively. The values of AIV and ACV are within the standard specification value for road material, cement concrete pavement and wearing surfaces of $30 \%$ and $45 \%$ maximum. Therefore the rock units are very excellent as aggregate for road pavement construction and categorized as strong aggregate in terms of quality for road pavement. It is also observed that porosity and specific gravity are the major parameters that show strong positive correlations $(\geq 0.5)$ with important geotechnical parameters such as shear strength, unconfined compressive strength, and point load strength index.
\end{abstract}

Keywords: Construction material, Aggregate, Pavement, Aggregate impact value, Aggregate crushing value, Point load strength index.

Citation | Falowo Olumuyiwa Olusola (2019). Engineering Properties of Some Basement Rocks of Nigeria as Aggregate in Civil Engineering Pavement Construction. Asian Review of Environmental and Earth Sciences, 6(1): 28-37.

History:

Received: 10 June 201

Revised: 12 July 2019

Accepted: 20 August 2019

Published: 1 October 2019

Licensed: This work is licensed under a Creative Commons

Attribution 3.0 License (oc) EY

Publisher: Asian Online Journal Publishing Group

\section{Contents}

1. Introduction

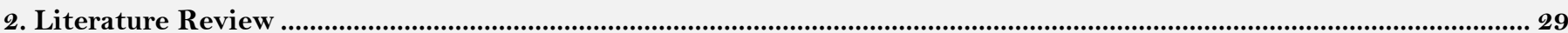

3. Description of Study Area

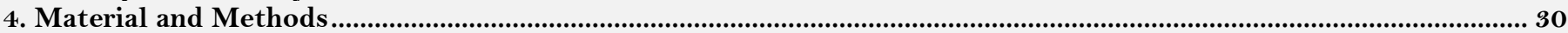

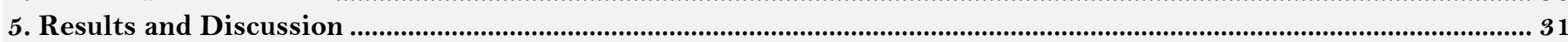

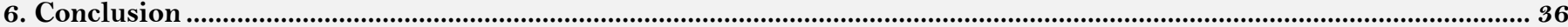

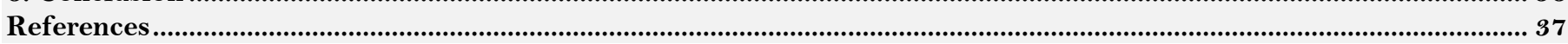

(n) Transparency: The author confirms that the manuscript is an honest account of the study was reported; that no vital study as planned have been explained.

Ethical: This study follows all ethical practices during writing. 


\section{Contribution of this paper to the literature}

The present study was able contribute to the existing knowledge by providing some geological information and engineering properties of some basement rocks of Southwestern Nigeria, as aggregates in civil engineering construction especially pavements; since aggregates are principal materials in pavement construction which can take the form of either stabilized or unstabilized base or sub-base courses. The information is very crucial and pertinent to designing high quality roads in the study area. In addition the work would also be useful in selecting the rock types for quarry, for the production of aggregates for optimum use in sustainable highway construction.

\section{Introduction}

Rock is one of the geomaterial used in construction in form of concrete, aggregate, building stone, and armourstone [1-4]. The suitability of rock for any civil engineering construction work depends on its physical property [5] and this is one of the basic goals of rock mechanics: to provide useful information and methods for predicting failure strength and associated parameters such as strain to failure and the effect of porosity and elastic moduli [6]. For ages rocks have been used as a construction material because it's readily availability either in form of igneous, sedimentary, or metamorphic rock. Although rocks requires little energy for extraction and processing. Indeed, rock is used more or less as it is found except for the seasoning, shaping and dressing that is necessary before it is used for civil engineering construction purposes. However the volume of material that can be quarried; the ease with which it can be quarried [6] the wastage consequent upon quarrying; and the cost of transportation; as well as its appearance and physical properties [7, 8] are the determining factors whether a rock would reworked as construction material. Also texture, appearance, porosity, durability [9-11] etc. are also desirable qualities of aggregates. Crushed rock is produced for a number of purposes, the chief of which are for concrete and road aggregate [12-14]. Approximately $75 \%$ of the volume of concrete consists of aggregate, therefore its properties have a significant influence on the engineering behaviour of concrete [12]. Aggregate is divided into coarse and fine types, the former usually consisting of rock material that is less than $40 \mathrm{~mm}$ and larger than $4 \mathrm{~mm}$ in size. The latter is obviously less than $4 \mathrm{~mm}$. Fine types less than $75 \mathrm{~mm}$ should not exceed $10 \%$ by weight of the aggregate [12]; [15].

\section{Literature Review}

Aggregate constitutes the basic material for road construction and is quarried in the same way as aggregate for concrete [16, 17]. Because it forms the greater part of a road surface, aggregate has to bear the main stresses imposed by traffic, such as slow-crushing loads and rapid-impact loads, and has to resist wear. Therefore, the rock material used should be fresh and have high strength $[12] ;[18,19]$. In addition, the aggregate used in the wearing course should be able to resist the polishing action of the traffic. The properties of road aggregate are related to the texture and mineralogical composition of the rock from which it was derived. Most igneous and contact metamorphic rocks meet the requirements demanded of good roadstone [15]; [20]. On the other hand, many rocks of regional metamorphic origin are either cleaved or schistose and are therefore unsuitable for roadstone. This is because they tend to produce flaky particles when crushed. Such particles do not achieve good interlock and, consequently, impair the development of dense mixtures for surface dressing. The amount and type of cement and/or matrix material that bind grains together in a sedimentary rock influence roadstone performance. The shape of aggregate particles is an important property and is governed mainly by the fracture pattern within a rock mass. The surface texture of aggregate particles largely determines the strength of the bond between the cement and themselves. A rough surface creates a good bond, whereas a smooth surface does not.

Many researchers [21-24] have tremendously contributed to knowledge in the aspects of compositional features and petrotectonic significance of quartzite and quartz-schist. Studies on the compressive strength of artificial composite rock materials in relation to their moisture content in Malaysia [25] emphasized probable complex engineering challenges due to variation in the rock composition. Akpokodje [26] studied certain rock aggregates for the Nigerian Basement rocks. His findings show that the aggregates are good engineering materials based on both compressive strength and water absorption characteristics. Adebisi and Adeyemi [27] confirmed the exclusive sensitivity of gneisses in South-west Nigeria to moisture content among other properties. The present study tries to employ field disposition and more importantly, some basic physical/geotechnical properties of the rocks in northern part of Ondo, Southwestern Nigeria to elucidate further on their usefulness in civil engineering construction especially in the area of concreting, and aggregates in pavement construction.

\section{Description of Study Area}

The study area is located within the northern part of Ondo State, Nigeria Figure 1. The selected areas include Owo, Akoko, and Ose. These areas are located within longitudes $5^{\circ} 20^{\prime} \mathrm{E}$ and $6^{\circ} 10^{\prime} \mathrm{E}$ and latitudes $6^{\circ} 30^{\prime} \mathrm{N}$ and $7^{\circ} 40^{\prime} \mathrm{N}$. The area is accessible through the Benin - Ifon highway, Abuja - Lokoja Highway and Ado-Akure highway. The study area has a topographical elevation varying from $40 \mathrm{~m}-750 \mathrm{~m}$ above the sea level. The northern part of the study area is a rugged terrain (i.e. hilly) especially in Akoko area [28]. The annual rainfall ranges between 1000 and $1800 \mathrm{~mm}$, with a mean annual rainfall of $1500 \mathrm{~mm}$, and average wet days of about 100 . The mean annual temperature is between $21^{\circ} \mathrm{C}$ and $33^{\circ} \mathrm{C}$ with mean temperature of $24^{\circ} \mathrm{C}$ and mean humidity of $80 \%$ [29]. 


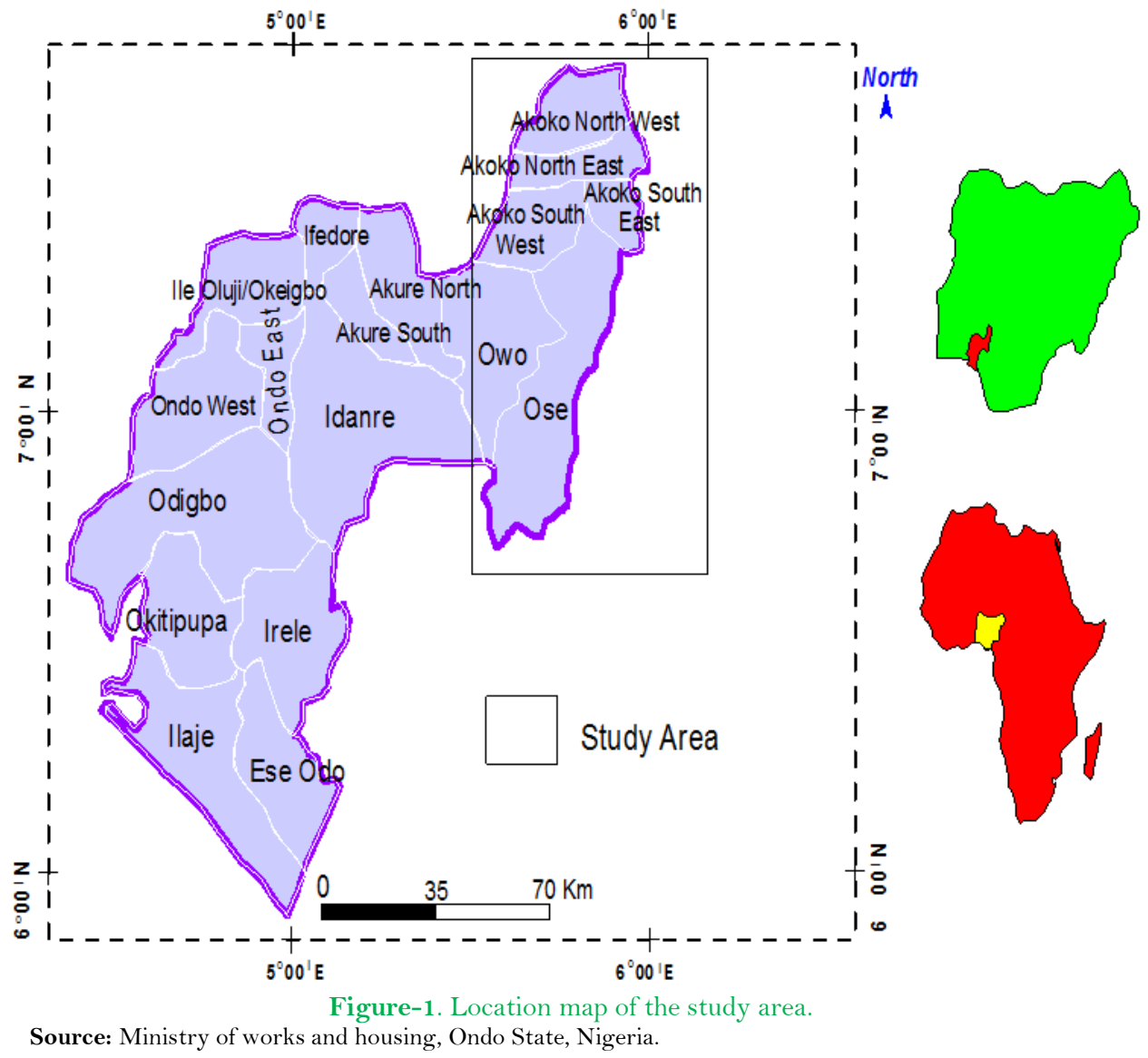

The geology of study area falls within the southwestern basement complex Figure 2 and consists of migmatite, granites, granodiorite, granite gneiss, fine grained quartzite, charnockite, pegmatite and quartzo-feldspathic veins, schist, and quartz schist. These rock types dominate Owo and Akoko areas, notably along Owo - Oba Akoko, Iwaro - Akungba, Akungba - Supare, Ikare, Epinmi, Sosan, Oke Agbe, and Ido Ani. The migmatite complex which is the most widespread basement rock in the area is mainly medium grained gneiss. They are strongly foliated rocks frequently occurring as outcrops. On the surface of these outcrops, severely contorted, alternating bands of dark and light coloured minerals can be seen. These bands of light coloured minerals are essentially feldspar and quartz, while the dark coloured bands contain abundant biotite. A small proportion of the area especially to the northeast, overlies the coarse grained granites and gneisses, which are poor in ferromagnesian minerals. These rocks are covered by regoliths with thickness variation across the town. Sand, clayshale, limestone, grift, sandstone, shale, coal, sandstone, and mudstone dominated the southern parts. The sedimentary rocks/deposit is mainly of the post Cretaceous sediments and the Cretaceous Abeokuta Formation.

\section{Material and Methods}

In total, eight rock samples were collected from different lithological units in the study area which include porphyritic Granite, fine grained Granite, Migmatite, Granite gneiss, Quartz schist, Granodiorite, Charnockite, and Quartzite Figure 2 and labelled as S1-S8. The sites where the samples were taken are shown in Figure 3. Their geotechnical properties which comprises moisture content determination, Aggregate impact value (AIV), Aggregate crushed value (ACV), Point load strength test, specific gravity, Water absorption test, Unconfined compression test, and direct shear strength test. The values of the presented rock properties were predominantly determined as an arithmetic average of two to five rock specimen tests. All laboratory tests were carried out in accordance with ASTM D- 2216 [30] and ISRM [31] for physical properties such as density, porosity, void ratio, moisture content and water absorption of the samples. The aggregate impact value (AIV) and aggregate crushed value (ACV) were prepared using BS 812: Part 110-112 British Standard Institution 1377 [32]. ISRM [31] IS: 2386 - part -3 for specific gravity determination for coarse aggregate.

Porosity was measured by dividing the amount of water filling the pore spaces, deduced from weight of each sample by density of water at room temperature. Void ratio was calculated based on the dry weight of each rock sample by subtracting one from the product of the sample volume and density, divided by the mass of the sample. Density was estimated from the ratio of bulk mass of each sample to its bulk volume. The mass of each specimen was determined after drying to a constant mass at a temperature of $105^{\circ} \mathrm{C}$ for 24 hours, and allowing it to cool in the desiccator for about 30 minutes. The volume of each sample was measured from its dimension, while water absorption was calculated as percentage by weight of water absorbed in terms of oven-dried weight of each sample. All numerical data obtained from the measured physical properties were subjected to statistical analysis, including regression plots in order to establish the relationship between the measured physical properties.

The unconfined compressive strength, direct shear strength, point load test were determined as outlined in ISRM [33]. For Point Load, the corrected Point Load Strength Index, $I_{S_{(50)}}$ was calculated using Equation 1. 


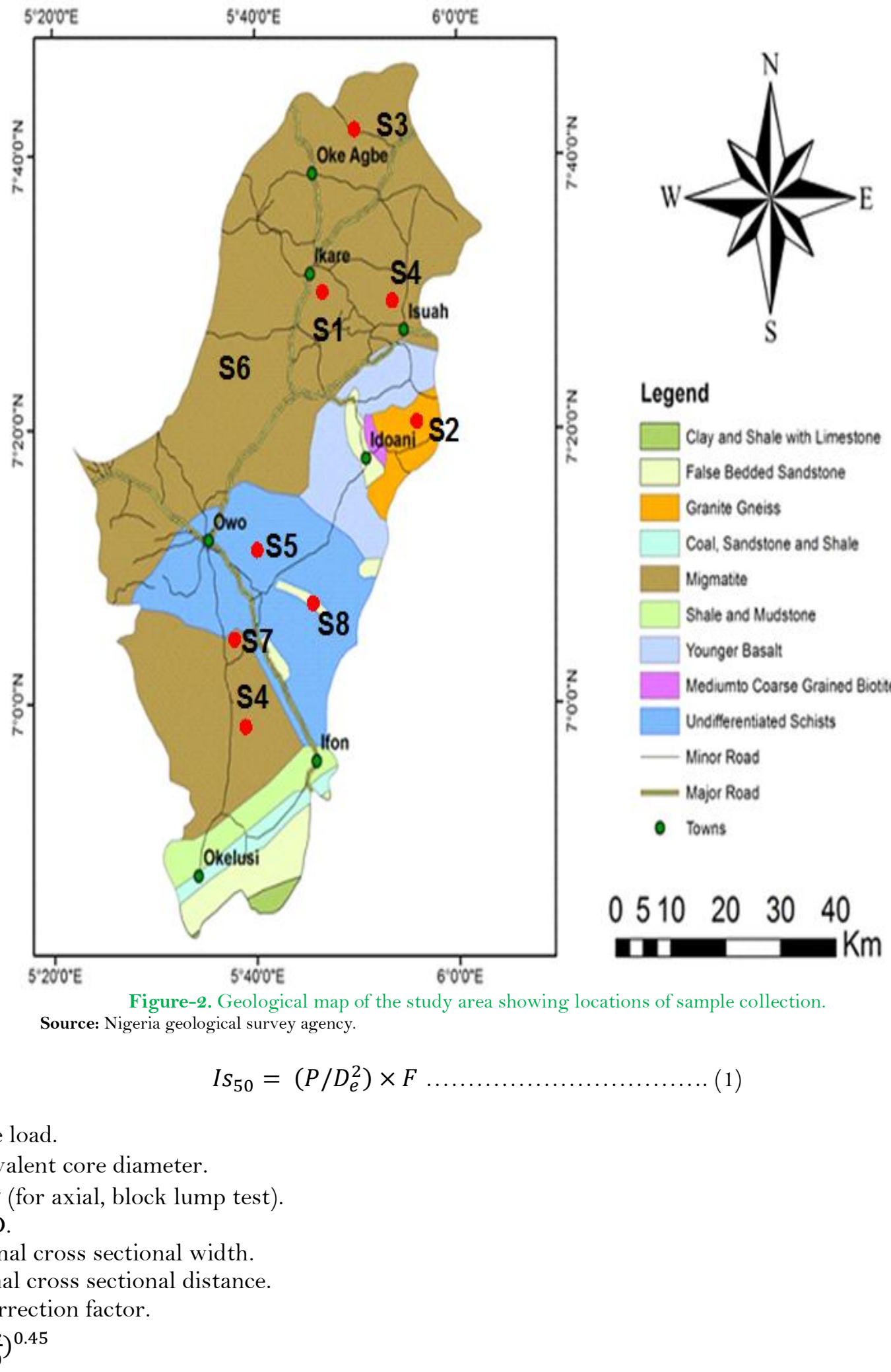

\section{Results and Discussion}

The results of the physical properties of the tested rock samples are summarized in Table 1 and 2 . The natural moisture content of rock samples varies from $0.15 \%$ in Quartzite to $0.43 \%$ in Granodiorite. The water absorption potential of the samples ranges between $0.27 \%$ (Quartzite) and $0.82 \%$ (porphyritic Granite).

Water content is one of the most important factors influencing rock strength. Considerable research has been carried out to investigate rock strength under both dry and water saturated conditions. According to these results, the petrophysical properties of rocks decrease with increasing moisture. Quartzite is a metamorphosed arenaceous rock with granulose texture. Predominantly composed of quartz. Quartzite is usually thought of as thermally metamorphosed rocks but regional metamorphism also produces them. The low moisture content of the quartzite could have as a result of degree of metamorphism which increases the mineral bonding, while the high water obtained in Granodiorite may be attributed to their texture.

The specific gravity of the samples is between 2.65 (Granite) and 2.73 (Granodiorite/Charnockite). The relatively high values obtained for Granodiorite and Charnockite could attributed to their mineral composition, as they tend to contain less quartz but high ferromagnesian minerals which denser and heavier in weight. The values of specific gravity obtained correlated well with range of values for crystalline rocks as reported in Anon [34] and Blyths and Freitas [35]. 


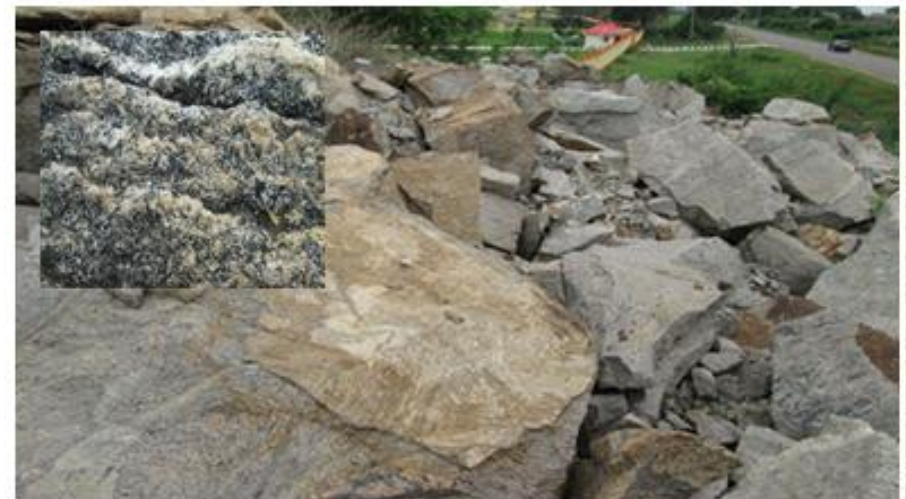

(a) Fined Grained Granite \& Porphyritic Granite obtained at Ikare and Ido Ani re spectively

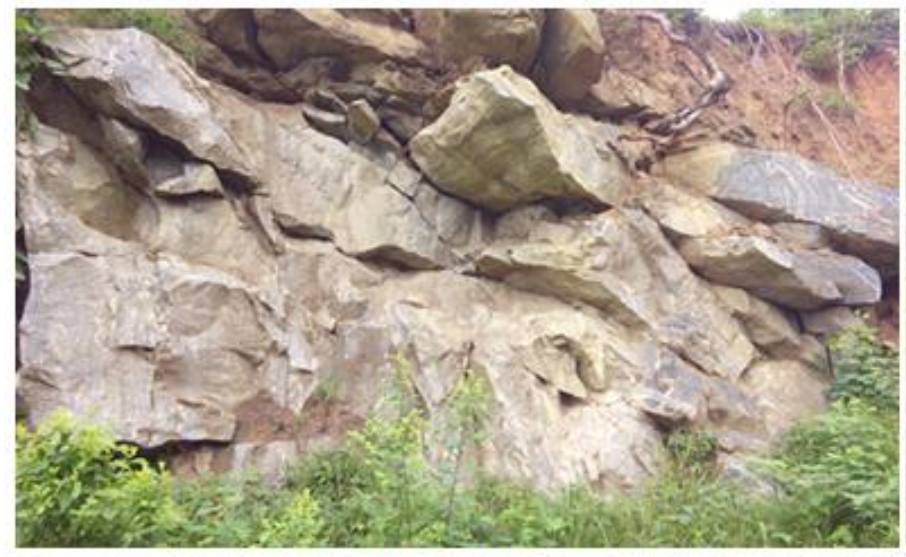

(c) Migmatite at Oke Agbe

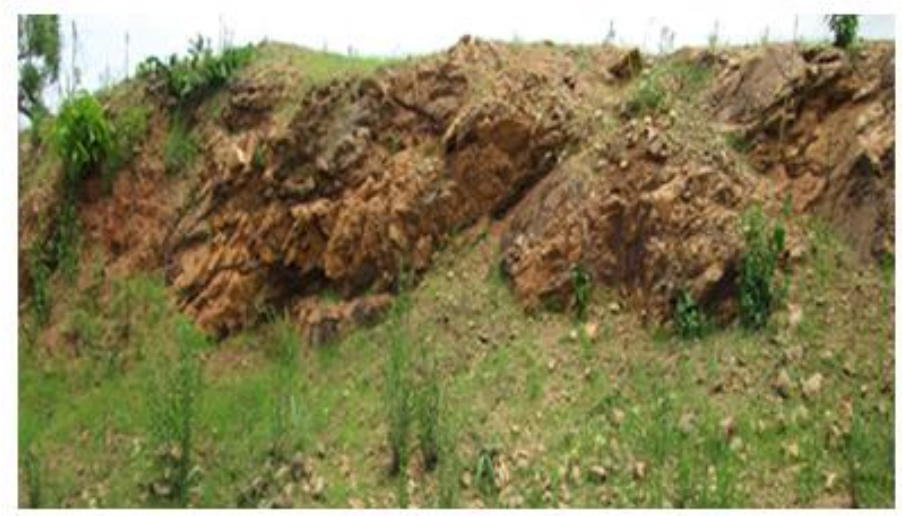

(e) Schist in Owo

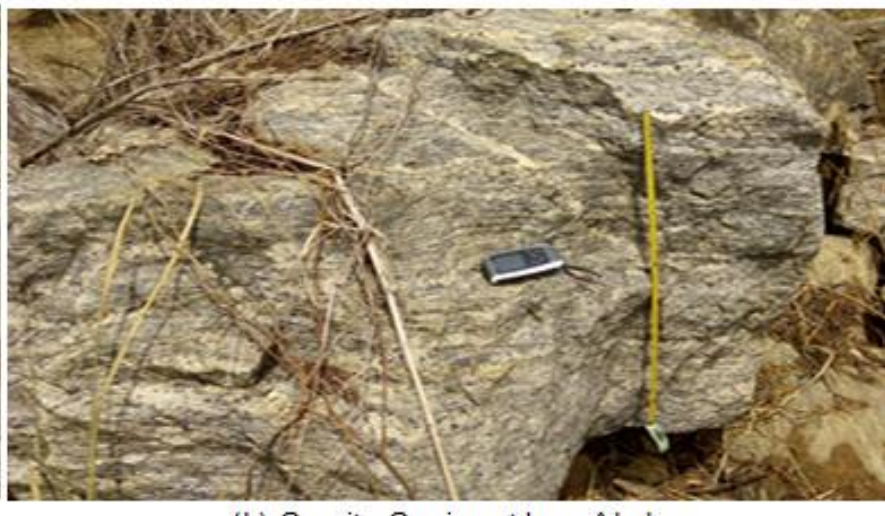

(b) Granite Gneiss at Isua Akoko

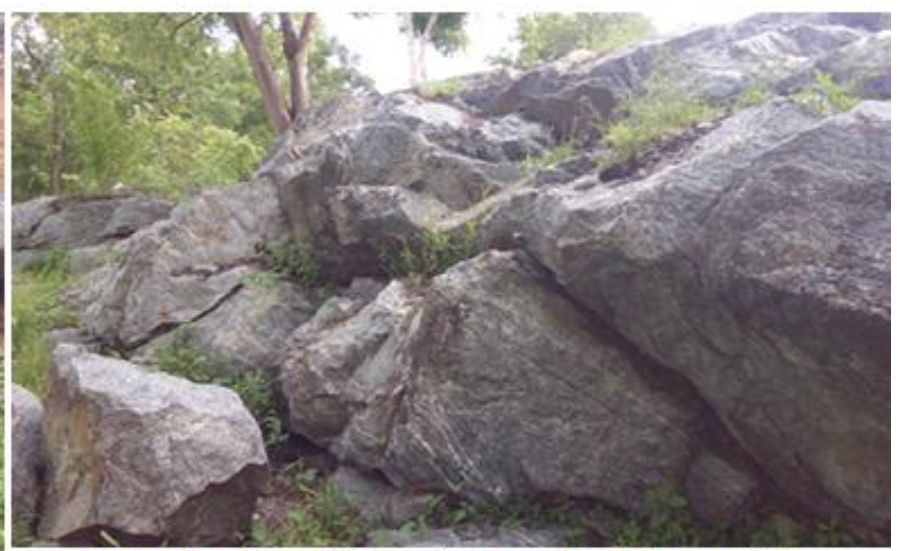

(d) Granite - Granodiorite with associated Charnockite along Ipele - Ifon

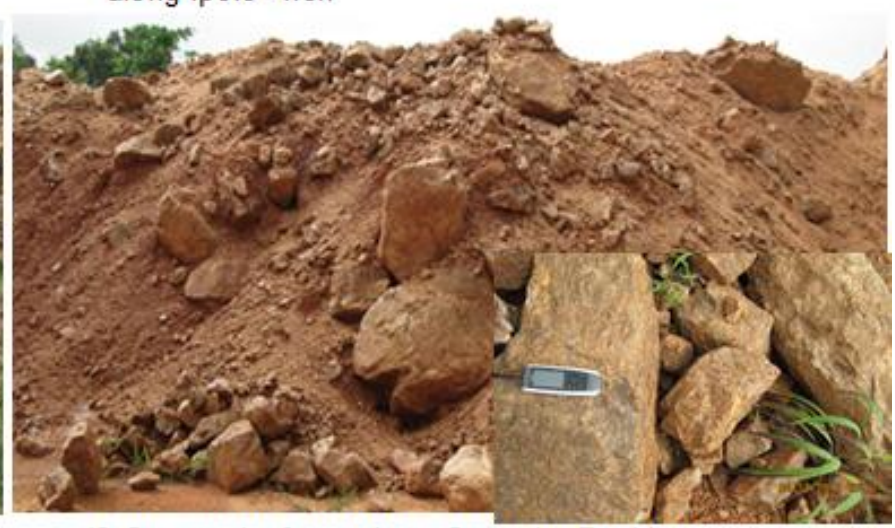

(f) Quarry site from where Quartzite Boulders were obtained

$1 \mathrm{~m}$

Source: Fieldwork, 2017.

Figure-3. Various sites where representative samples of the rock units are collected.

The water absorption of the rock samples varies from 0.27 for Quartzite to 0.82 for porphyritic Granite. However the values obtained for granite (approx. 0.5) and Quartzite (approx. 0.3) are very close to those reported in Bell [12] for roadstone properties of some common aggregate in Table 3.

The Dry Unit Weight recorded for the rock units ranges from 26.59 (Quartzite) to $27.04 \mathrm{KN} / \mathrm{m}^{3}$ (Quartz Schist), while porosity ranges between 0.18 (Quartzite) - 0.46 (porphyritic Granite). According to Anon [34] in Table 4, the rock samples can be regarded as high to very high rocks, since their dry unit weight is greater than $25 \mathrm{KN} / \mathrm{m}^{3}\left(25 \mathrm{Mg} \mathrm{m}^{-3}\right)$. This is consistent with the determined density of metamorphic rocks [5]. The rock units are characterized by low porosity as their values are less than 1 . This implies that they are compact and impervious in their natural states. Rock porosity depends on not only the density of the solid matrix material, but also the density of pore fluids as well as saturation.

The aggregate impact value (AIV) gives a relative measure of the resistance of the aggregate to sudden shock or impact. The particular purpose which an aggregate is meant to serve requires the aggregate to have a particular strength which is usually stated in the specification Table 5. This test provides a method for measuring this strength. The values of AIV ranges from 11.2 (Quartzite/Granite Gneiss) to 17.3 (Charnockite). Gneiss has a rough banding or foliation, in which pale coloured bands of quartz and feldspar lie parallel with bands or streaks of mafic minerals Figure 3; the mafic minerals are mainly biotite, hornblende, or in some cases pyroxene. Biotite is often accompanied by muscovite, and garnets are common accessory minerals. A gneiss breaks less readily than a schist and commonly splits across the foliation; it is often coarser in texture than most schists, though some gneisses are relatively fine-grained [35]. Therefore based on this characteristics of gneiss, this might be responsible for low AIV recorded relative to other rock samples. From Table 5, the rock units can categorized as strong aggregate in terms of quality for road pavement. These values of AIV of the rock samples correlate well with some rock units of the same lithology (granite and quartzite) reported by Bell [12]. The aggregate crushing value provides a relative measure of resistance to crushing under a gradually applied compressive load. Aggregate used in road construction should be strong enough to resist crushing under traffic wheel loads. If the aggregates are weak, the stability of the pavement structure is likely to be adversely affected. To achieve a high quality of 
pavement, aggregate possessing low aggregate crushing value should be preferred. The ACV recorded a range of 18.4 (Quartzite) - 25.2 (Charnockite). The aggregate crushing value for road material; cement concrete pavement should not exceed 30\%, while ACV for wearing surfaces should not exceed 45\%. Therefore the rock units are very excellent as aggregate for road pavement construction.

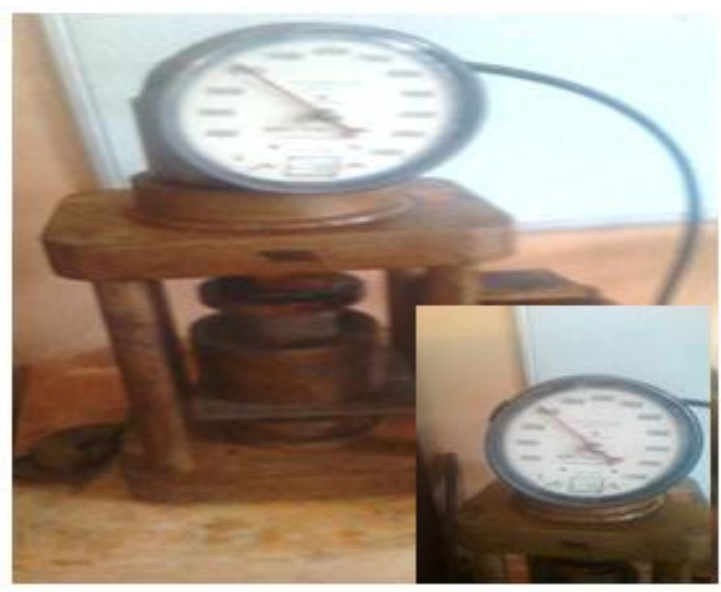

(a) ACV Test Machine

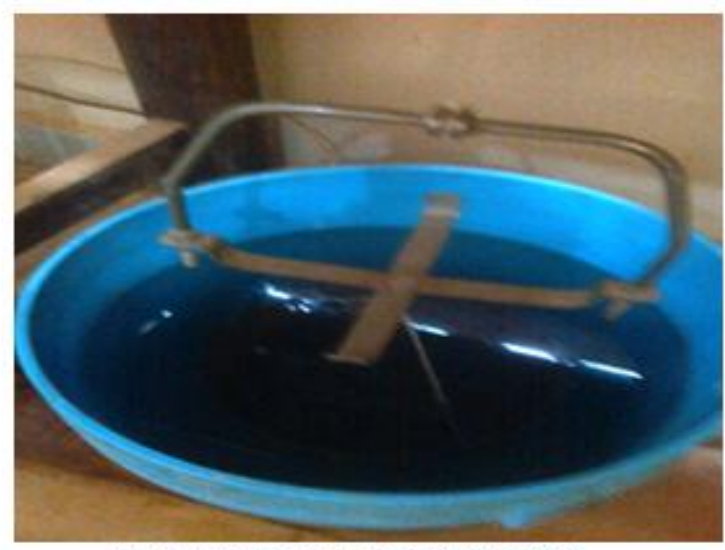

(c) Aggregates and Basket in water for Water Absorption test and specific gravity

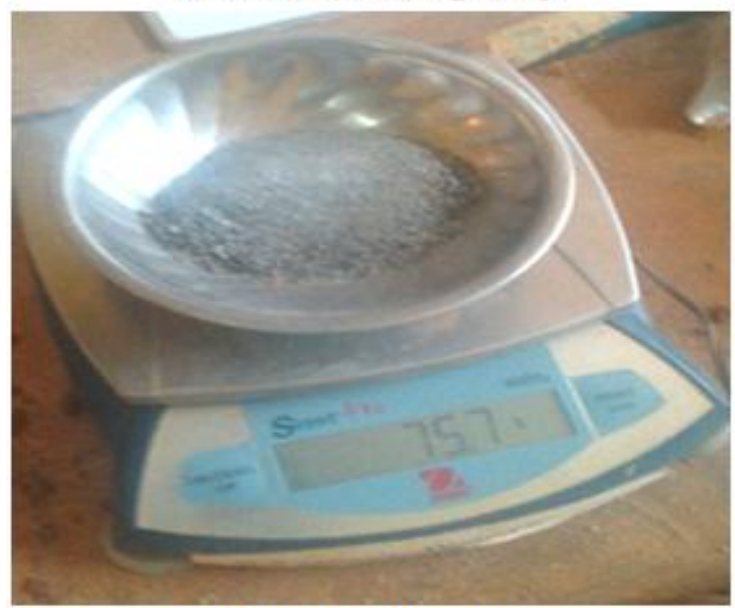

(e) Weight Measuring Scale

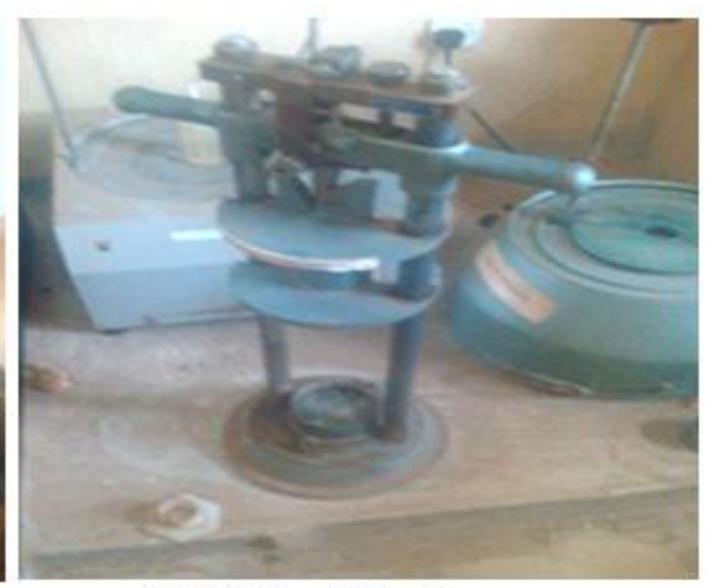

(b) AIV Test Machine

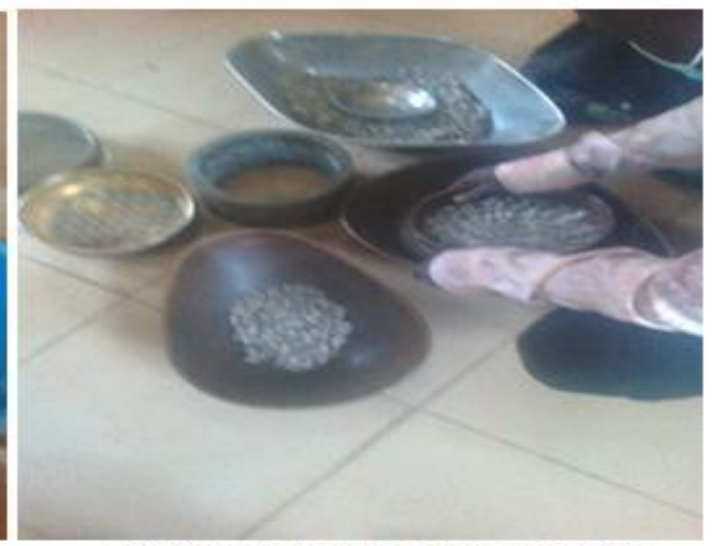

(d) Separation of Aggregate with $2.2 \mathrm{~mm}$ Sieve after Crushing

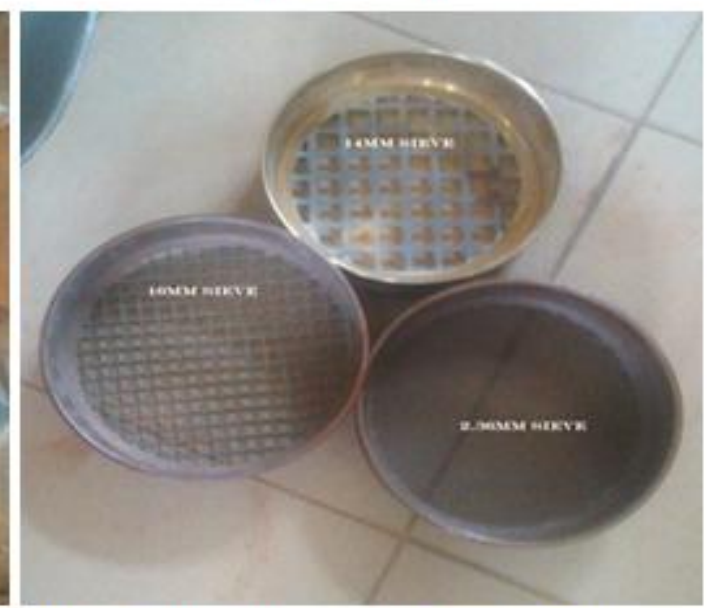

(f) Different Sieve Sizes of $2.36 \mathrm{~mm}$,

Figure-4. Pictures of some equipment and processes undertaken in the course of the laboratory analysis. Source: Federal University of Technology, Akure, Nigeria.

The point load strength test is used as an index test for strength classification of rock materials. The test method is performed to determine the point load strength index $\left(I s_{50}\right)$ of rock specimens. The point load strength index (PLSI) of the samples ranges between 7.40 and 9.87. Charnockite is characterized with relatively high PLSI of the sampled rocks. The Charnockite obtained in the study area are fine to medium-grained, equigranular and massive, sometimes porphyritic. Charnockitic rocks constitute one of the important petrological units within the Precambrian Basement Complex of Nigeria. They are generally characterized by their dark greenish to greenish grey appearance which makes them easily recognizable in hand specimen. They usually contain quartz + plagioclase + alkali feldspar + orthopyroxene + clinopyroxene + hornblende \pm biotite \pm fayalite. Accessory minerals are usually zircon, apatite, and iron ores [36, 37]. Therefore high value of PLSI observed in the Charnockite could be as a result of its texture and chemical composition. Hence based on Table 6 according to Franklin and Broch [38] the rocks can be categorized as very high strength rock materials with corresponding compressive strength between 50 and $160 \mathrm{MPa}$, which correlates with the actual values obtained for the sampled rocks i.e. 121 - 185.3MPa. Subsequently using Table 7 and 8, according to Geological Society, International Association of Engineering Geologist and International Society for Rocks Mechanics, they are very strong rock units. 


\begin{tabular}{|c|c|c|c|c|c|c|c|c|c|}
\hline $\begin{array}{c}\text { Sample } \\
\text { no. }\end{array}$ & Rock unit & MC (\%) & AIV & $\mathrm{ACV}$ & $\begin{array}{c}\text { PLSI } \\
\text { (MPa) }\end{array}$ & SG & $\begin{array}{l}\text { WA } \\
(\%)\end{array}$ & $\begin{array}{c}\text { UCS } \\
\text { (MPa) }\end{array}$ & $\begin{array}{c}\text { ST } \\
\text { (MPa) }\end{array}$ \\
\hline $\mathrm{S} 1$ & Porphyritic Granite & 0.41 & 15.2 & 24.2 & 7.40 & 2.65 & 0.82 & 121.1 & 60.5 \\
\hline $\mathrm{S} 2$ & Granite & 0.39 & 13.1 & 23.1 & 8.08 & 2.69 & 0.48 & 143.1 & 71.6 \\
\hline S3 & Migmatite & 0.34 & 14.4 & 23.1 & 8.05 & 2.66 & 0.57 & 122.1 & 61.1 \\
\hline $\mathrm{S} 4$ & Granite Gneiss & 0.38 & 11.2 & 19.7 & 8.82 & 2.70 & 0.33 & 127.5 & 63.7 \\
\hline $\mathrm{S} 5$ & Quartz Schist & 0.24 & 12.4 & 22.2 & 8.89 & 2.66 & 0.66 & 159.4 & 79.7 \\
\hline S6 & Granodiorite & 0.43 & 12.1 & 21.1 & 9.52 & 2.73 & 0.44 & 170.2 & 85.1 \\
\hline $\mathrm{S} 7$ & Charnockite & 0.34 & 17.3 & 25.2 & 9.87 & 2.72 & 0.47 & 165.9 & 82.9 \\
\hline S8 & Quartzite & 0.15 & 11.2 & 18.4 & 8.84 & 2.65 & 0.27 & 185.3 & 92.6 \\
\hline
\end{tabular}

Note: MC-moisture content, AIV-aggregate impact value, ACV-aggregate crushed value PLSI-point load strength index, WA-water absorption, UCSunconfined compressive strength, ST-shear strength.

Table-2. Results of the dry unit weight, porosity, and water content of the rock samples.

\begin{tabular}{c|c|c|c|c}
\multicolumn{5}{c}{ Table-2. Results of the dry unit weight, porosity, and water content of the rock samples. } \\
\hline Sample no. & Rock unit & Dry unit Wt. $\left(\mathbf{K N} / \mathbf{m}^{\mathbf{3}}\right)$ & Porosity (\%) & Water content (\%) \\
\hline S1 & Porphyritic Granite & 26.72 & 0.46 & 0.16 \\
\hline S2 & Granite & 26.82 & 0.37 & 0.23 \\
\hline S3 & Migmatite & 26.90 & 0.37 & 0.15 \\
\hline S4 & Granite Gneiss & 26.71 & 0.38 & 0.29 \\
\hline S5 & Quartz Schist & 27.04 & 0.29 & 0.12 \\
\hline S6 & Granodiorite & 27.03 & 0.30 & 0.22 \\
\hline S7 & Charnockite & 26.79 & 0.31 & 0.19 \\
\hline S8 & Quartzite & 26.59 & 0.18 & 0.11 \\
\hline
\end{tabular}

Table-3. Some representative values of the roadstone properties of some common aggregates.

\begin{tabular}{c|c|c|c|c}
\hline Rock type & $\begin{array}{c}\text { Water } \\
\text { absorption }\end{array}$ & $\begin{array}{c}\text { Specific } \\
\text { gravity }\end{array}$ & $\begin{array}{c}\text { Aggregate } \\
\text { crushing value }\end{array}$ & $\begin{array}{c}\text { Aggregate impact } \\
\text { value }\end{array}$ \\
\hline Basalt & 0.9 & 2.91 & 14 & 13 \\
\hline Dolerite & 0.4 & 2.95 & 10 & 9 \\
\hline Granite & 0.8 & 2.64 & 17 & 14 \\
\hline Micro-granite & 0.5 & 2.65 & 12 & 11 \\
\hline Hornfels & 0.5 & 2.81 & 13 & 20 \\
\hline Quartzite & 1.8 & 2.63 & 20 & 12 \\
\hline Limestone & 0.5 & 2.69 & 14 & \\
\hline Greywacke & 0.5 & 2.72 & 10 & \\
\hline
\end{tabular}

Table-4. Dry density and porosity.

\begin{tabular}{c|c|c|c|c}
\hline Class & Dry density $\left(\mathbf{M g ~ m}^{-3}\right)$ & Description & Porosity (\%) & Description \\
\hline 1 & Less than 1.8 & Very low & Over 30 & Very high \\
\hline 2 & $1.8-2.2$ & Low & $30-15$ & High \\
\hline 3 & $2.2-2.55$ & Moderate & $15-5$ & Medium \\
\hline 4 & $2.55-2.75$ & High & $5-1$ & Low \\
\hline 5 & Over 2.75 & Very high & Less than 1 & Very low \\
\hline \multicolumn{2}{l}{ Source: After Blyths and Freitas $[35]$}
\end{tabular}

Source: After Blyths and Freitas [35].

The shear strength of the samples varies from 60.5 (porphyritic Granite) to 92.6 MPa (Quartzite). Quartzite is derived from the conversion of siliceous rock such as sandstone through the process of metamorphism. The original quartz grains of the sandstone (and siliceous cement if present) are recrystallized as an interlocking mosaic of quartz crystals. Therefore Quartzite in its massive, unweathered state is very strong, in terms of crushing and shear strengths.

Figures 6-11 show regression plots of the physical parameters measured. Porosity, water absorption, specific gravity (SG), and moisture content (MC) are chosen as independent variables, while shear strength (SS), unconfined compressive strength (UCS), AIV, ACV, and PLSI are dependent variables. Figure 4 shows fair positive relationship $\left(\mathrm{r}^{2}=0.4078\right)$ between WA against P. SS and USC have a high positive coefficient of correlation with porosity i.e. $\mathrm{r}^{2}=0.8291 ; 0.8287$ respectively Figure 5 and 6 .

Low positive correlation coefficient exists between UCS and MC (0.31); AIV and WA (0.25); AIV and P (0.15); $\mathrm{ACV}$ and $\mathrm{P}(0.32)$. However ACV shows a fair positive correlation with WA $\left(\mathrm{r}^{2}=0.4815\right)$, while PLSI recorded a good correlation coefficient of 0.5 with specific gravity Figure 11. Therefore from the regression analysis plots, porosity and specific gravity are the major properties that show strong positive correlations with shear strength, unconfined compressive strength, and point load strength index [39].

\begin{tabular}{c|l}
\hline \multicolumn{2}{c}{ Table-5. Classification of aggregate based on aggregate impact value. } \\
\hline AIV $\mathbf{( \% )}$ & Quality of aggregate \\
\hline$<10$ & Exceptionally strong \\
\hline $10-20$ & Strong \\
\hline $20-30$ & Satisfactorily for road surfacing \\
\hline$>35$ & Weak for road surfacing \\
\hline Source: Thuro and Plinninger $[39]$
\end{tabular}

Source: Thuro and Plinninger [39]. 


\begin{tabular}{|c|c|c|}
\hline Class & Point load strength index (MPa) & $\begin{array}{c}\text { Equivalent uniaxial compressive } \\
\text { strength (MPa) }\end{array}$ \\
\hline Extremely high strength & Over 10 & Over 160 \\
\hline Very high strength & $3-10$ & $50-160$ \\
\hline High strength & $1-3$ & $15-60$ \\
\hline Medium strength & $0.3-1$ & $5-16$ \\
\hline Low strength & $0.1-0.3$ & $1.6-5$ \\
\hline Very low strength & $0.03-0.1$ & $0.5-1.6$ \\
\hline Extremely low strength & Less than 0.03 & Less than 0.5 \\
\hline
\end{tabular}

Table-7. Classification of compressive strength of rocks.

\begin{tabular}{c|c|c}
\hline Class & Compressive strength (MPa) & Term \\
\hline 1 & Over 200 & Extremely strong \\
\hline 2 & $100-200$ & Very strong \\
\hline 3 & $50-100$ & Strong \\
\hline Source: After Anon $[40]$ & \multicolumn{2}{c}{}
\end{tabular}

Table-8. Grades of unconfined compressive strength.

\begin{tabular}{c|c|c|c|c|c}
\hline \multicolumn{2}{c|}{ Geological Society, Anon [40] } & \multicolumn{2}{|c}{ IAEG [34] } & \multicolumn{2}{c}{ ISRM [41] } \\
\hline Term & Strength $(\mathrm{MPa})$ & Term & Strength $(\mathrm{MPa})$ & Term & Strength $(\mathrm{MPa})$ \\
\hline Very weak & Less than 1.25 & Weak & Under 15 & Very low & Under 6 \\
\hline Weak & $1.25-5.00$ & $\begin{array}{c}\text { Moderately } \\
\text { strong }\end{array}$ & $15-50$ & Low & $6-10$ \\
\hline Moderately weak & $5.00-12.50$ & Strong & $50-120$ & Moderate & $20-60$ \\
\hline Moderately strong & $12.50-50$ & Very strong & $120-230$ & High & $60-200$ \\
\hline Strong & $50-100$ & $\begin{array}{c}\text { Extremely } \\
\text { strong }\end{array}$ & Over 230 & Very high & Over 200 \\
\hline Very strong & $100-200$ & & & & \\
\hline Extremely strong & Over 200 & & & &
\end{tabular}

Source: After Anon [41].

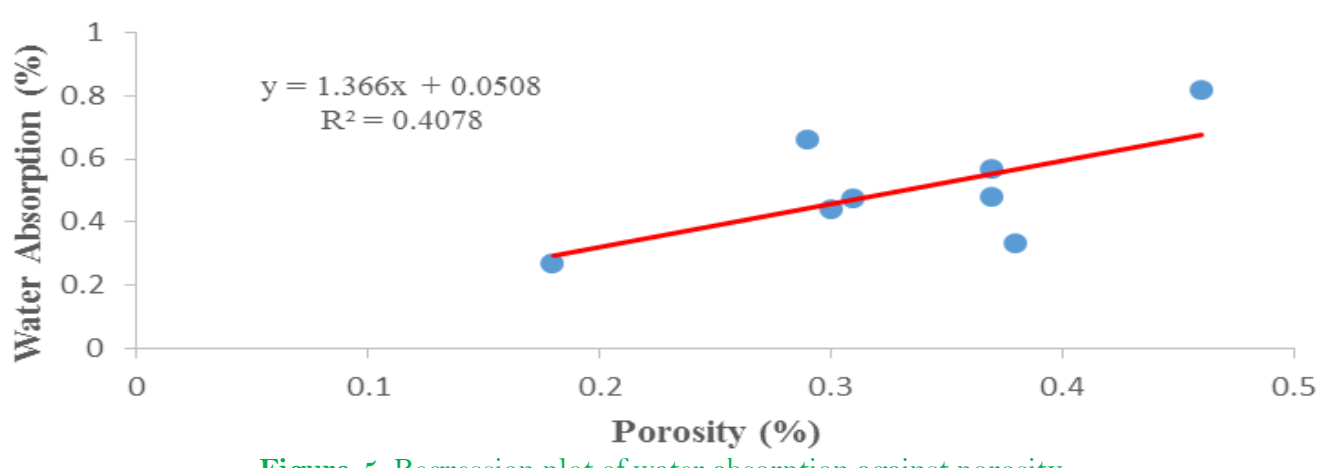

Source: Data analysis.

Figure-5. Regression plot of water absorption against porosity.

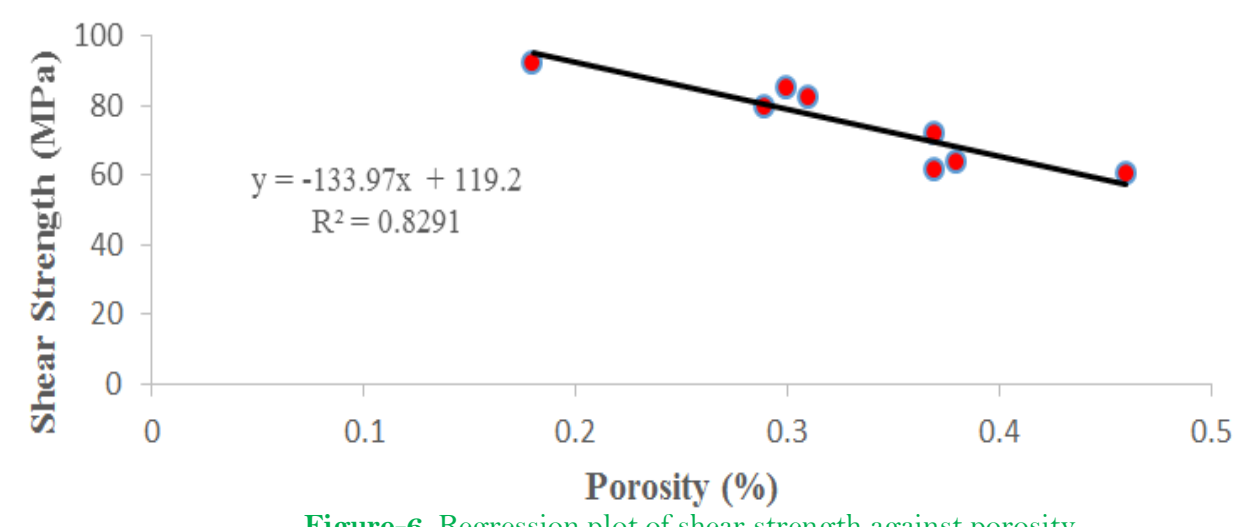

Source: Data analysis.

Figure-6. Regression plot of shear strength against porosity.

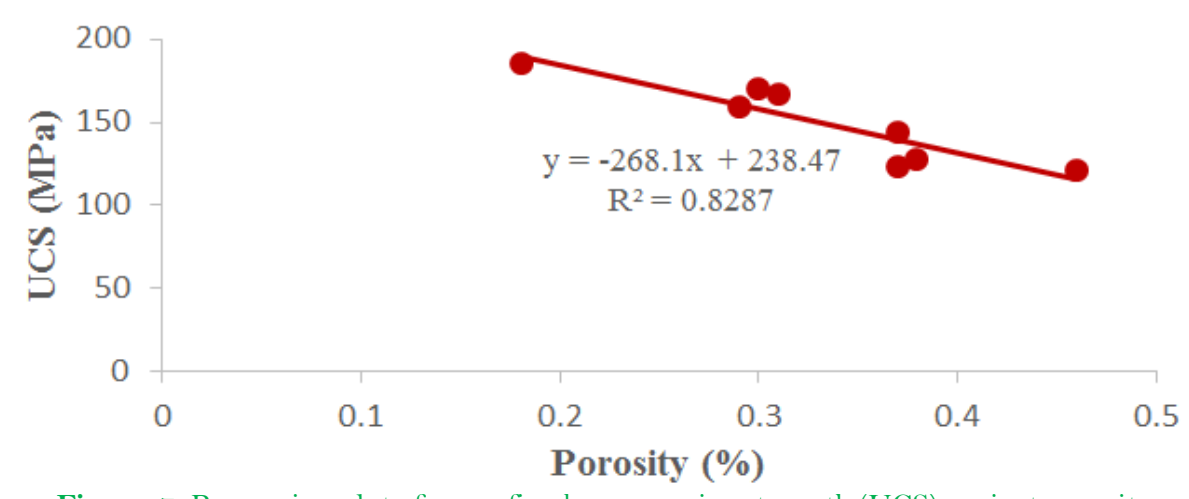

Figure-7. Regression plot of unconfined compressive strength (UCS) against porosity. Source: Data analysis. 


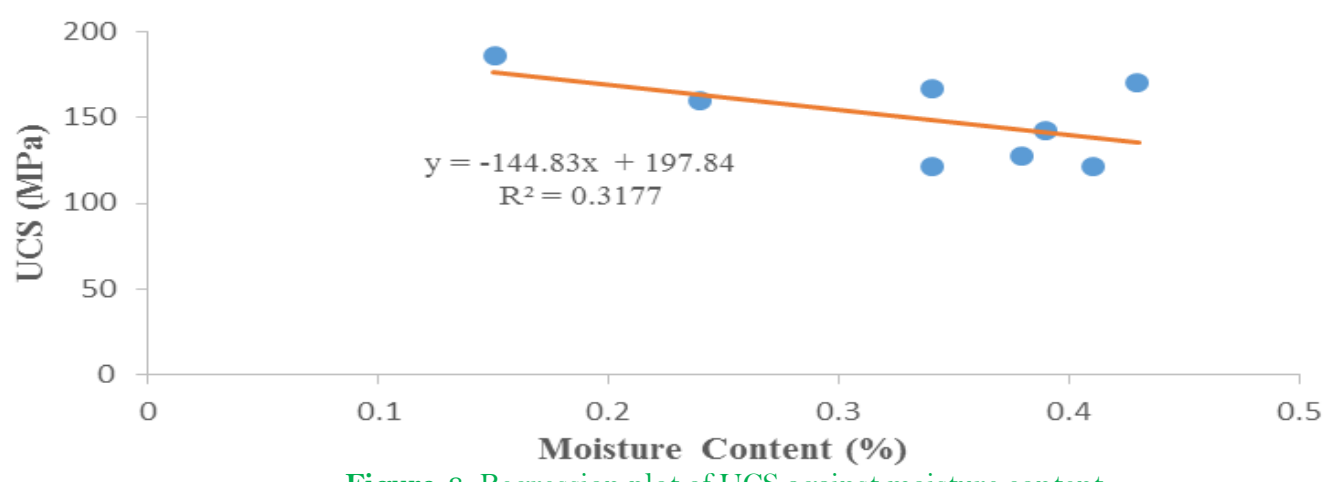

Source: Data analysis.

Figure-8. Regression plot of UCS against moisture content.

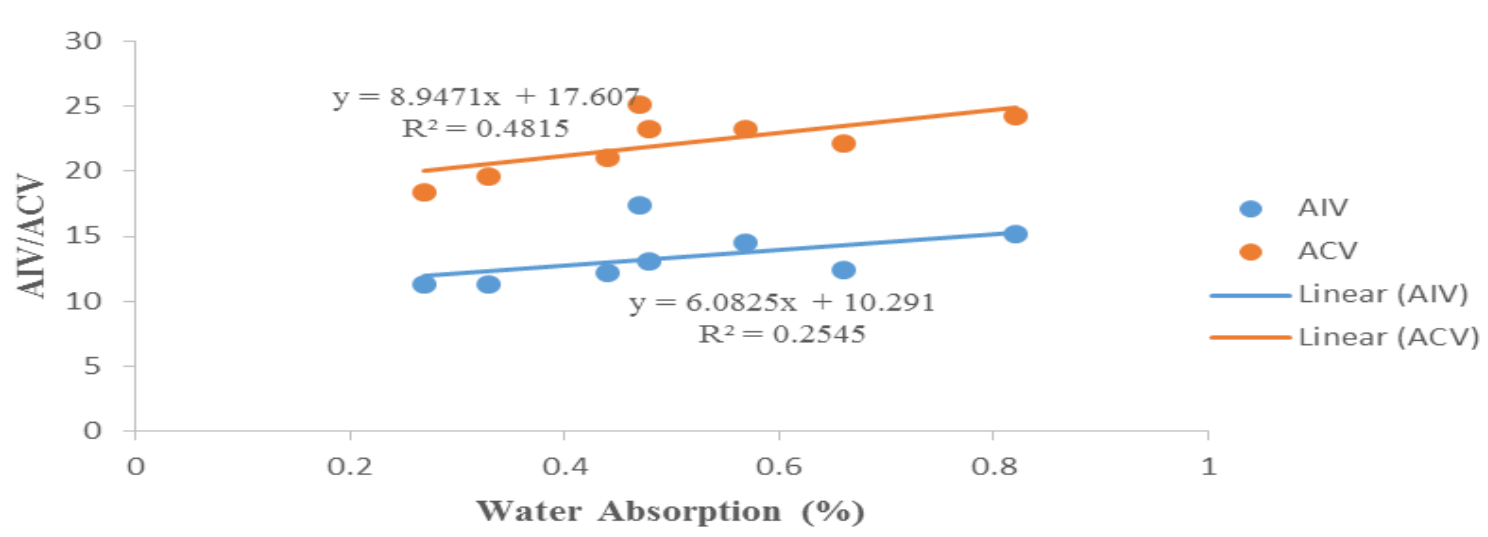

Figure-9. Regression plot of aggregate impact value and aggregate crushing value against water absorption. Source: Data analysis.

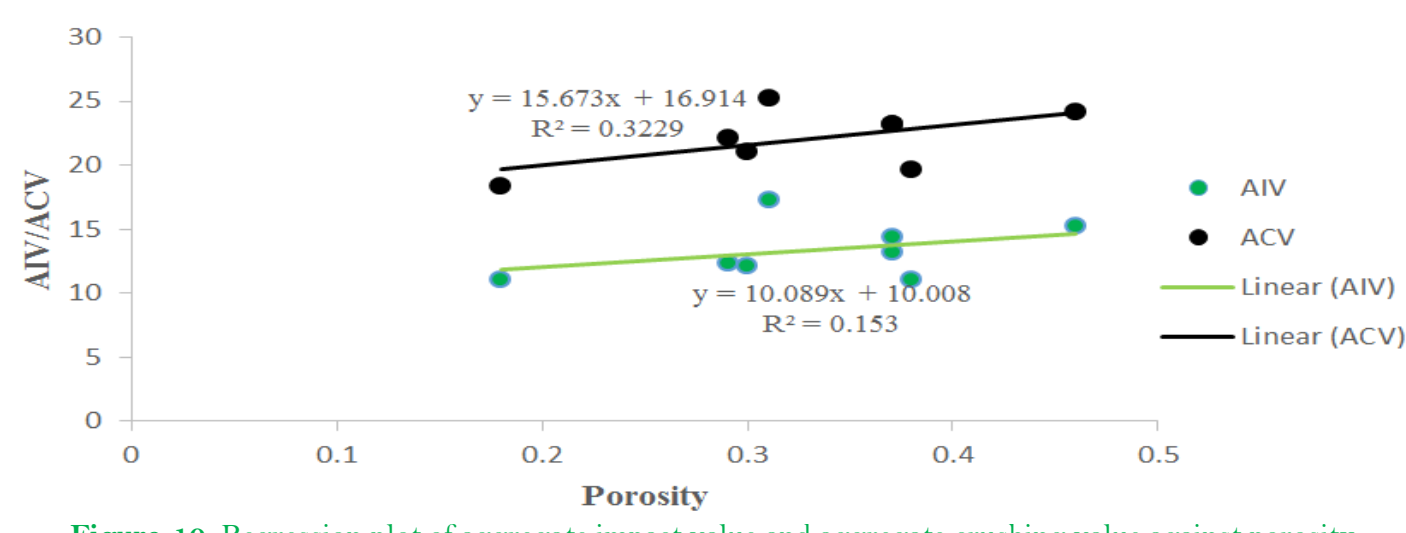

Figure-10. Regression plot of aggregate impact value and aggregate crushing value against porosity. Source: Data analysis.

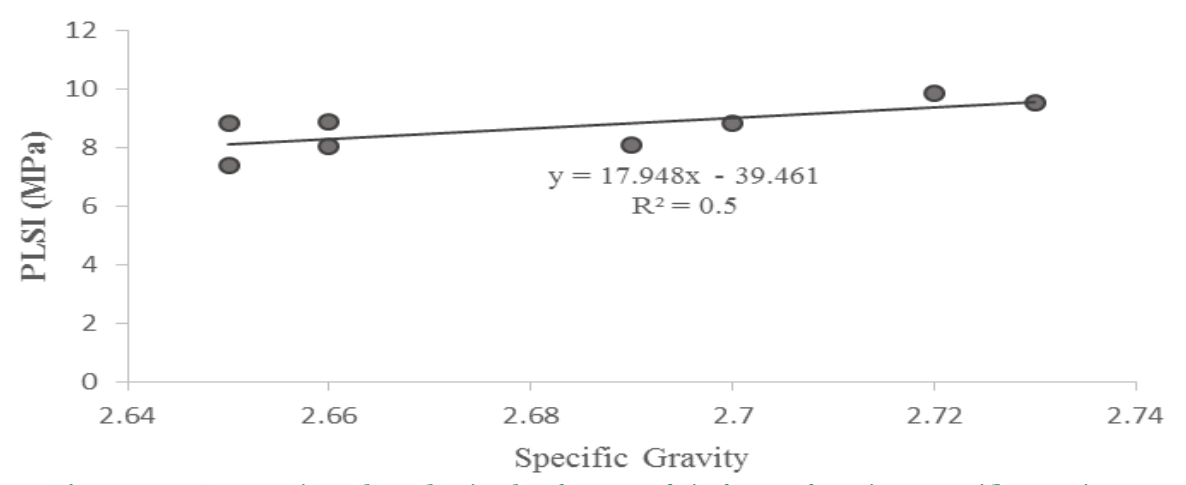

Figure-11. Regression plot of point load strength index and against specific gravity. Source: Data analysis.

\section{Conclusion}

The degree at which rocks can be used as building stones, armourstone, aggregate in pavement construction, and concrete depends on physical properties, which is a reflection of compositional features. In order to achieve this parameters such as moisture content, dry density, porosity, specific gravity, aggregate impact value, aggregate crushing value, point load strength index, unconfined compressive strength, and shear strength were determined from eight different lithological rock units. Findings show that the rocks are characterized by low porosity, very high strength on the basis of point load strength index and shear strength. The samples show strong quality as aggregate in pavement construction. However Charnockite seems to have excellent physical properties which could attributed to its texture and mineral composition. It is also observed that porosity and specific gravity are the major parameters that show strong positive correlations with important geotechnical parameters such as shear strength, unconfined compressive strength, and point load strength index. 


\section{References}

[1] A. B. Hawkins, "Geomaterials in construction: An introduction," Quarterly Journal of Engineering Geology, vol. 24, pp. 1-2, 1991.

[2] W. J. French, "Introduction: Applied petrology - the stability of concrete aggregates," Quarterly Journal of Engineering Geology, vol. 13 , p. 205,1980

[3] A. R. Clark and J. S. Palmer, "The problem of quality control and selection of armourstone," Quarterly Journal of Engineering Geology, vol. 24, pp. 119-122, 1991. Available at: https://doi.org/10.1144/gsl.qjeg.1991.024.01.12.

P. G. Fookes, "Geomaterials," Quarterly Journal of Engineering Geology, vol. 24, pp. 3-15, 1991 D. P. Krynine and W. R. Judd, Principles of geotechnics and geology, 1 st ed. New Delhi, India: McGraw Hill, 1958.

F. Ighrakpata, O. Molua, E. Igherighe, and J. Idialu, "Comparison of the strength of two different rock samples," The Pacific Journal of Science and Technology, vol. 13, pp. 384-390, 2012.

[7] A. Yavuz, N. Turk, and M. Koca, Geological parameters affecting the marble production in the quarries along the Southern flank of the Menderes Massif, in SW Turkey. Engineering Geology, vol. 80, pp. 214-241, 2005. Available at: https://doi.org/10.1016/j.enggeo.2005.05.003.

[8] D. Jefferson, "Building stone: The geological dimension," Quarterly Journal of Engineering Geology and Hydrogeology, vol. 26, pp. 305319, 1993. Available at: https://doi.org/10.1144/gsl.qjegh.1993.026.004.06.

[9] A. Arizzi and G. Cultrone, "The influence of aggregate texture, morphology and grading on the carbonation of non-hydraulic (aerial) lime-based mortars," Quarterly Journal of Engineering Geology and Hydrogeology, vol. 46, pp. 507-520, 2013. Available at: https://doi.org/10.1144/qjegh2012-017.

[10] T. E. Dibb, D. W. Hughes, and A. B. Poole, "Controls of size and shape of natural armourstone," Quarterly Journal of Engineering Geology, vol. 16, pp. 31-42, 1983a. Available at: https://doi.org/10.1144/gsl.qjeg.1983.016.01.03.

[11] T. E. Dibb, D. W. Hughes, and A. B. Poole, "The identification of critical factors affecting rock durability in marine environments," Quarterly Journal of Engineering Geology, vol. 16, pp. 149-161, 1983b. Available at: https://doi.org/10.1144/gsl.qjeg.1983.016.02.08. F. G. Bell, Engineering geology. Jordan Hill, Oxyford, United Kingdom: Elsevier Ltd, 2007.

[13] J. Bullas, "Modification of the formula used in the determination of the ten per cent fines value of aggregate," Quarterly Journal of Engineering Geology, vol. 23, pp. 187-188, 1990. Available at: https://doi.org/10.1144/gsl.qjeg.1990.023.02.07.

[14] I. B. Cameron, "Wearing course aggregates in Northern Ireland," Quarterly Journal of Engineering Geology, vol. 5, pp. 81-83, 1972. Available at: https://doi.org/10.1144/gsl.qjeg.1972.005.01.09.

[15] P. Fookes, "An introduction to the influence of natural aggregates on the performance and durability of concrete," Quarterly Journal of Engineering Geology and Hydrogeology, vol. 13, pp. 207-229, 1980.

[16] I. Sims, "Quality and durability of stone for construction," Quarterly Journal of Engineering Geology and Hydrogeology, vol. 24, pp. 6773, 1991. Available at: https://doi.org/10.1144/gsl.qjeg.1991.024.01.06.

[17] I. Sims, "Sand, gravel and crushed rock aggregates for construction purposes: Geological society engineering group working party," Quarterly Journal of Engineering Geology and Hydrogeology, vol. 19, pp. 325-338, 1986. Available at: https://doi.org/10.1144/gsl.qjeg.1986.019.03.13.

[18] I. Collis and R. A. Fox, Geological society, aggregates: Sand, gravel and crushed rock aggregates for construction purposes (Eds. I. Collis and R.A. Fox) vol. 1: Engineering Geology Special Publication, 1985.

[19] J. P. Latham, Geological society, advances in aggregates and armourstone evaluation (ed. J.-P. Latham): Engineering Geology Special Publication, 1998.

[20] P. Fookes and A. Poole, "Some preliminary considerations on the selection and durability of rock and concrete materials for breakwaters and coastal protection works," Quarterly Journal of Engineering Geology and Hydrogeology, vol. 14, pp. 97-128, 1981. Available at: https://doi.org/10.1144/gsl.qjeg.1981.014.02.03.

[21] C. Okonkwo, "Structural geology of basement rocks of Jebba area, Nigeria," Journal of Mining and Geology, vol. 28, pp. 203-209, 1992 .

[22] C. Okonkwo, "Geochemistry of quartzites and quartz-mica schist in Jebba area, Nigeria," Journal of Mining and Geololgy, vol. 28, pp. 203-209, 2005.

[23] C. T. Okonkwo and J. A. Winchester, Geochemistry of semi-Pelitic Schist Konga Area, Northwestern Nigeria. Global Journal of Pure and Applied Sciences, vol. 7, pp. 303 - 309, 2001 . Available at: https://doi.org/10.4314/gjpas.v7i2.16249.

[24] A. A. Elueze and O. A. Okunlola, Petrochemical and petrogenetic characteristics of metasedimentary rocks of Lokoja - Jakura Schist Belt, Central Nigeria. Journal of Mining and Geology, vol. 39, pp. 163 - 173, 2003. Available at: https://doi.org/10.4314/jmg.v39i1.18787.

[25] Z. Mohamed, K. Mohamed, and C. G. Chun, "Uniaxial compressive strength of composite rock material with respect to shale thickness ratio and moisture," Electronic Journal of Geotechnical Engineering, vol. 13, pp. 1-10, 2008.

[26] E. Akpokodje, "Properties of some Nigeria rock aggregates," Journal of Mining and Geology, vol. 23, pp. 185-190, 1992.

[27] N. O. Adebisi and G. O. Adeyemi, "Compressive strength properties of gneisses in Southwestern Nigeria," Quarterly Publication of Scientific Society of Mineral Wealth Technology Geotechnology, vol. 156, pp. 43-50, 2001.

[28] R. W. Marans and W. Rodgers, Toward an understanding of community satisfaction: In Hawley A.H. and Rock V.P. (Eds), Metropolitan America in Contemporary Perspective. London: Wiley Publishing, 1975.

[29] N. P. Iloeje, A new geography of Nigeria. Lagos: Longman Nig. Ltd., 1981.

[30] ASTM D-2216, American standards for testing and materials - standard test methods for laboratory determination of moisture content of soil and rock. West Conshohocken, PA: ASTM International, 1992.

[31] B. E. ISRM, Suggested methods: Rock characterization, testing and monitoring. Pergamon, Oxford: ISRM Commission on Testing Methods, 1981

[32] British Standard Institution 1377, Methods of test for soil for civil engineering purposes. London: BS1377, 1990.

[33] J. Franklin, "Suggested method for determining point load strength," International Journal of Rock Mechanics and Mining Sciences, vol. 22, pp. 53-60, 1985. Available at: https://doi.org/10.1016/0148-9062(85)92985-7.

[34] O. Anon, "Classification of rocks and soils for engineering geological mapping. Part 1: Rock and soil materials," Bulletin of the International Association of Engineering Geology, vol. 19, pp. 355-371, 1979. Available at: https://doi.org/10.1007/bfo2600503.

[35] F. G. H. Blyths and M. H. D. Freitas, A geology for engineers, 7th ed. Jordan Hill, Oxyford, United Kingdom: Edward Arnold, Elsevier Butterworth-Heinemann, 1984.

[36] V. O. Olarewaju, The charnockitic intrusives of Nigeria. In: Oshi O (Ed), The basement complex of Nigeria and its mineral resources (A Tribute to Prof. M. A. O. Rahaman). Ibadan: Akin Jinad \& Co, 2006.

[37] N. G. Obaje, Geology and mineral resources of Nigeria. London New York: Springer Dordrecht Heidelberg, 2009.

[38] J. L. Franklin and E. Broch, "The point load test," International Journal Rock Mechanics and Mining Science, vol. 9, pp. 669-697, 1972.

[39] K. Thuro and R. J. Plinninger, Scale effects in rock strength properties. Part 2: Point load test and point load strength index. Rock mechanics - a challenge for society, Särkkä ङ Eloranta (Eds.): Swets \& Zeitlinger Lisse, 2001.

[40] Q. Anon, "The description of rock masses for engineering purposes," Journal of Engineering Geology, vol. 10, pp. $355-388,1977$.

[41] O. Anon, "Basic geotechnical description of rock masses. International society of rock mechanics commission on the classification of rocks and rock masses," International Society of Rock Mechanics and Mining Sciences and Geomechanical Abstracts, vol. 18, pp. 85-1 10, 1981. 